\author{
A.S. Tuleubekov ${ }^{1 *}$, B.B. Meirbayev² ${ }^{\text {ID }}$, A.B. Doskozhanova ${ }^{3}$ \\ ${ }^{1}$ International Information Technologies University, Kazakhstan, Almaty \\ ${ }^{2}$ Al-Farabi Kazakh National University, Kazakhstan, Almaty \\ ${ }^{3}$ International Information Technologies University, Kazakhstan, Almaty \\ *e-mail: a.tuleubekov1982@gmail.com
}

\title{
IMMATERIALITY OF THE FIRST BEING IN THE AL-FARABI'S METAPHYSICS
}

This article reveals the non-material nature of the First Existence in the metaphysical system of Abu Nasr al-Farabi. The purpose of this analysis is to describe the evidence base that al-Farabi gives in order to identify the immateriality of the First Being. The system of argumentation of the immateriality of the First Being is part of the description of the perfection of the First Being, which al-Farabi presents within the framework of general cosmology. Justifying immateriality, al-Farabi basically follows the Aristotelian interpretation. However, he added a lot from the worldview of the Neoplatonists. As you know, the Neoplatonists paid great attention to emanation. According to the Neoplatonists, the Supreme Reason exists everywhere, and He is eternal in time. Al-Farabi borrowed this idea from the Neoplatonists, thanks to which he expanded his cosmology. In this regard, al-Farabi is a universal interpreter who synthesized the view of the Peripatetics and Neoplatonists into a single metaphysical system. At the same time, alFarabi created his own cosmological system. It contains both the ideas of ancient and medieval Islamic scholars and their own vision of heavenly metaphysics. For a deep understanding of the nature of bodily substances, al-Farabi divided the heavenly structure into two levels. The first level - above moon - covers the ontology of the First Being and the sphere of celestial intellects. The second level - sublunary describes everything that is in the sphere of the Earth. Thus, the idea of the immaterial nature of the First Being is an important part of his deep metaphysical system.

Key words: the First Being, metaphysics, material world, intangible nature.

\section{А.С. Төлеубеков ${ }^{1 *}$, Б.Б. Мейірбаев ${ }^{2}$ А.Б. Аосқожанова}

'Халықаралық Ақпараттық технологиялар университеті, Қазақстан, Алматы қ. ${ }^{2}$ Әл-Фараби атындағы Қазақ, ұлттық университеті, Қазақстан, Алматы қ.

${ }^{3}$ Халықаралық Ақпараттық технологиялар университеті, Қазақстан, Алматы қ. *e-mail: a.tuleubekov1982@gmail.com

\section{Әл-Фараби метафизикасындағы \\ Бірінші Боммыстың материалдық емес мәні}

Бұл мақалада әл-Фарабилің метафизикалық жүйесіндегі Бірінші Болмыстың материалдық, емес мәніне жалпы сипаттама берілген. Бұл талдаудың мақсаты - Бірінші болмыстың материалды емес екендігін дәлелдеу үшін әл-Фараби қолданған дәлелдерді сипаттау. Бірінші болмыстың материалды емес екендігінің дәлелдеу жүйесі әл-Фараби жалпы космология шеңберінде ұсынатын Бірінші болмыстың жетілуін сипаттаудың бір бөлігі болып табылады. Өзінің метафизикалық, жүйесінде әл-Фараби Аристотельдің түсіндірулеріне сүйенеді. Алайда, ол неоплатониктер ілімдеріне ерекше көңіл бөлді. Өздеріңіз білетіндей, неоплатонистер эманацияға үлкен мән берді. Неоплатонистердің пікірінше, мәңгі болып, Жоғарғы Ақыл барлық жерде кең таралған. Бұл илеяны әл-Фараби неоплатонистерден алды, соның арқасында ол өзінің космологиясын кеңейтті. Осыған байланысты әл-Фараби перипатетиктер мен неоплатонистердің көзқарастарын біртұтас метафизикалық жүйеге біріктірген жан-жақты ғалым болды. Сонымен бірге әл-Фараби өзінің космологиялық жүйесін құрды. Онда ежелгі және ортағасырлық ислам ғалымдарының идеялары да, аспан метафизикасы туралы өзіндік көзқарастары да бар. Аене заттарының табиғатын терең түсіну үшін әл-Фараби аспан құрылымын екі деңгейге бөлді. Бірінші деңгей ай үстіндегі - Бірінші болмыстың онтологиясын және аспан интемлектерінің сферасын қамтиды. Екінші деңгей - ай астындағы - Жер шарындағы барлық нәрсені сипаттайды. Сонымен, Бірінші болмыстың материалдық емес табиғаты туралы идея оның терең метафизикалық жүйесінің маңызды бөлігі болып табылады.

Түйін сөздер: Алғашқы Себеп, космология, құдай әлемі, аспан сфералары. 


\title{
А.С. Тулеубеков ${ }^{1}$, Б.Б. Меирбаев ${ }^{2}$, А.Б. Аоскожанова ${ }^{3}$ \\ ${ }^{1}$ Международный университет информационных технологий, Казахстан, г. А^маты ${ }^{2}$ Казахский национальный университет имени аль-Фараби, Казахстан, г. Алматы ${ }^{3}$ Международный университет информационных технологий, Казахстан, г. А^маты e-mail: a.tuleubekov1982@gmail.com \\ Нематериальная сущность Первого Сущего в метафизике аль-Фараби
}

\begin{abstract}
В данной статье раскрывается нематериальная природа Первого Сущего в метафизической системе Абу Насыра аль-Фараби. Целью данного анализа является описание доказательной базы, которую приводит аль-Фараби с целью выявления нематериальности Первого Сущего. Система аргументации нематериальности Первого Сущего является частью описания совершенства Первого Сущего, которую аль-Фараби представляет в рамках общей космологии. Обосновывая нематериальность, аль-Фараби в основном следует аристотелевской интерпретации. ОАнако многое он добавил из мировоззрения неоплатоников. Как известно, неоплатоники уделяли большое вниманию эманации. Согласно неоплатоникам, Высший разум существует везде и Он вечен во времени. А^ь-Фараби заимствова^ эту идею неоплатоников, благодаря которой он расширил свою космологию. В этом отношении аль-Фараби является универсальным интерпретатором, который синтезирова^ взгляА перипатетиков и неоплатоников в еАиную метафизическую систему. В то же время а^ь-Фараби создал свою космологическую систему. В ней присутствуют как илеи античных и средневековых исламских ученых, так и собственное видение небесной метафизики. А^я глубокого понимания природы телесных субстанций, альФараби разбил небесную структуру на два уровня. Первый уровень - надлунный - охватывает онтологию Первого Сущего и сферы небесных интемлектов. Второй уровень - подлунный описывает все то, что находится в сфере Земли. Таким образом, идея о нематериальной природе Первого Сущего является важной частью его глубокой метафизической системы.
\end{abstract}

Кмючевые слова: Первый Сущий, метафизика, материальный мир, нематериальная природа.

\section{Introduction}

This article examines a detailed ontology of material and non-material criteria for determining entities associated with the essence of the First One. The ontological approach is primarily important here. As Martin Heidegger wrote: "In its modern usage, the word 'ontology' means as much as 'theory of objects' and indeed one which is in the first place formal. In this respect, it coincides with ancient ontology ('metaphysics')" (Heidegger, 1999). In this respect, a correct understanding of ontology itself and ontological consideration of something is important, especially if it concerns the ontology of the First One. In the sixth paragraph $(\S 6)$ of his On the Perfect State, Al-Farabi writes that, since in its nature the First One is not composed of matter (that is, matter does not precede the First One as the first basis of its existence), its essence is expressed as actual intellect. This part of explanation of the First One by al-Farabi is closely related to the Neoplatonist understanding of Nous, which forms a world order based on its own intellectual nature, which is in constant actualization and thus is identical with the universe itself. In other words, the emanation of the First One is the very process of the existence of the universe. "An important feature stressed by alFārābi is the identity between intellect and the divine essence. Since the First is immaterial, It must necessarily be an intellect ( $a q l$ ), as al-Fārābī considers all immaterial beings to be of an intellectual nature. More specifically, however, It is a perfect intellect that is not affected by any kind of deficiency (naqs) and plurality or complexity (kathrah), and which thus possesses a unitary and perfectly simple intellectual existence" (Janos, 2012). To be more precise, the First One is the actual intellect, which actualizes its own transcendent being in itself, revealing its own ontic being in the ontic form of self-knowledge. Although this is the realm of immaterial, it still presupposes existence. As Hegel writes: "Existence is immediate unity of being and reflection, and hence appearance; it comes from the ground and goes to the ground. The actual is the positedness of that unity, the relationship that has become identical with itself; hence, it is exempted from passing-over, and its externality is its energy; in that externality it is inwardly reflected; its being-there is only the manifestation of itself, not of an other" (Hegel, 1991). The latter is a form of existential unity (that is, the First One itself), but as actively knowing itself, that is, how nature discloses itself through the creation of the most intellectual actualities in the form of human intelligence. Of course, it is necessary to make a reservation here, which is that comparing human intelligence with the actual intellect of the One is not 
a comparison of incompatible entities, but a comparison of part and whole.

\section{Main body}

Beginning from al-Farabi, Islamic Peripatetics developed several approaches to the essence of the First One including the Neoplatonic doctrine of emanation which was very similar to that formulated by Proclus. From the First One comes the existence of the Second, which is also an absolutely incorporeal substance and which is not in matter (at the same time it is the first intellect). It comprehends its essence and the First One. Since it comprehends something from the First One, the existence of the Third follows inevitably from it. The Third is also not in matter; it is intellect by virtue of its substance. From it follows the existence of the sphere of fixed stars. This process of the outflow of one being, or intellect, from another continues up to the tenth intellect, corresponding to the spheres of Saturn, Jupiter, Mars, Sun, Mercury and Moon. The existence of the sphere of the Moon precedes the Eleventh being that follows from it, the last of those types of being that do not need matter as a basis for their existence, that is, they are intellects and intelligible objects. What follows is the hierarchy of sublunar beings, which are either natural or derived. These include fire, air, water, earth, minerals, plants, animals and, finally, man. Man completes the cosmic hierarchy.

Al-Farabi's ontology, along with his cosmology, is a rather complex and at the same time universal system, which is adequately explained by an expanded logical methodology. Al-Farabi says that the First One is the root cause of the existence of all beings, there is nothing more perfect than the First One, and nothing can precede the First One. As well, the First One is eternal in His existence, and its being is free from any matter and any subjectivity. Al-Farabi says about the unity of the First One that since the First One is a perfect essence, then its existence cannot belong to any other thing except itself. Therefore, the First One is one in its existence. But here it is important to note that the First One is devoid of 'subjectivity', that is, nothing definite can be said about the First One, as about a concrete thing. Since the First One is not matter and does not possess matter of any kind, it is in essence the actual intellect. That is, this corresponds to the existence of the First One. Therefore, the First One can be identified as the actual intellect. "An important feature stressed by al-Fārābī is the identity between intellect and the divine essence. Since the First is immaterial, It must necessarily be an intellect ( $a q l$ ), as al-Fārābī considers all immaterial beings to be of an intellectual nature. More specifically, however, It is a perfect intellect that is not affected by any kind of deficiency (naqs) and plurality or complexity (kathrah), and which thus possesses a unitary and perfectly simple intellectual existence" (Janos, 2012). This reasoning about the essence of the First One reveals another aspect of this issue, namely, the immateriality of the First One.

The immateriality of all entities that are in one way or another connected with the First One also concerns human nature, in particular, human consciousness. Al-Farabi pays special attention to this aspect, since human consciousness is directly related to the typology of intellects created by the Turkic thinker. Human consciousness is a local natural actualization of ontic actual intellect, which is completely identical to the First One. In other words, actual intellect is the current cause of the universe, which gives rise to the possibility of actualization for all forms of the material existence of nature and the universe. As Aristotle writes in Metaphysics, "matter exists as a potential state, just because it may attain to its form; and when it exists actually, then it is in its form" (Barnes, 1984). Therefore, speaking of the self-knowledge of actual intellect, we are talking about the knowledge of the universe by itself through those material-intellectual formations that people are as carriers of active intellect. "The affirmation of the existence of a separate Active Intellect leads al-Farabi to inquire about the cause of nature and the cause of the soul" (Morewedge, 1992). But the very essence of actual intellect, which, in a more active form, reaches the level of active intellect, remains as an ontic essence, that is, the First One itself. Moreover, the active intellect resides in substantiality of the natural states of objects even before they become the object of human cognition. If the previous types of intellect make their cognitive journey from the already explored further to the unknown, then the active intellect just acts in the opposite order. The active intellect is turned to natural perfection, that is, it first comprehends the most perfect of existing things. Thus, the very essence of the active intellect closes a life cycle of intellect in the frames of human cognition; as well, the active intellect is closely linked with the celestial bodies.

Based on the understanding of the First One in the metaphysics of al-Farabi, I can note that the First One expresses ontos. By its content, ontos is very close to the Western understanding, within which the concept of 'being' was formed. The essence of the West-centric 'being' was well described by Heidegger. He writes that Being "is of all concepts the 
one that is selfevident. Whenever one cognizes anything or makes an assertion, whenever one comports oneself towards entities, even towards oneself, some use is made of 'Being'; and this expression is held to be intelligible without further ado" (Heidegger, 1962). Or another understanding of the concept of 'being', which was spelled out by Hegel: "Being is the indeterminate immediate; it is free of determinateness with respect to essence, just as it is still free of any determinateness that it can receive within itself" (Hegel, 2010). However, we understand that al-Farabi's being as ontos has a slightly different, possibly more ontological and, at the same time, more dynamic meaning than the above descriptions carried out by Eurocentric thinkers. According to alFarabi, the ontos of the First One, by its semantic definition, is at the heart of real world, despite the fact whether real world is perceived by man, does the man have any effect on the universe or does the universe itself effect on a state of man in it. In all cases, when it comes to the real world, a man deals with the ontos of the First One, with its use in understanding the universe as an endlessly changing ontological process, i.e. as an ongoing being. We note here real world as a world in the process of its infinite formation, that is world as the process of emanation. It is important to keep in mind ontos as a property, that is, as something that is originally inherent in the First One.

Also, regarding actual intellect, no form precedes the actual intellect itself, since everything that gives form to something begins to actually comprehend. In this case, it may turn out that actual intellect is also comprehended by something that precedes it. Al-Farabi in this case claims that this preceding beginning, which can comprehend even actual intellect, can be matter, since what is intelligible is an object in ontological matter, for example, in material nature. That is, from the point of view of nature itself, matter in many ways allows the form to be the form of something material; i.e., matter precedes the possibility of the form to manifest itself in objects that have already taken forms.

However, all the above does not at all mean that actual intellect conflicts with matter or tries to avoid it. Here we are faced with the correct understanding of what can be 'immaterial'. "When we consider the immaterial, we must consider the way attachments are made within the material world - and how these attachments are implicated in producing things and people within their surroundings with profound implications for the way sociality is conceived and the varied sensuous attachments we make" (Buchli, 2015). Al-Farabi says that in order to avoid prob- lems with the ontological interpretation of the essence of the First One, it acts as an ontic essence both matter (which with the help of actual intellect has the ability to take forms) and the actual intellect itself. In fact, actual intellect is therefore called ' $a c$ tual', since its identity with the First One gives the universe an actual existence in the form of an active material nature that produces, through actual intelligence, various states of its existence. In other words, the First One acts as both matter and actual intellect for the purpose of carrying out the process of forming the material nature. Here, as we see, there is an explanation of the First One through four Aristotelian causes: 1) producing cause (actual intellect), 2) matter (nature), 3) form and 4) final cause.

In addition, al-Farabi emphasizes, if the actualization of an object occurs outside of material actualization, then in any case, actual intellect realizes the object in its existence, but already as an extra-material object, or an object in thought. These may include the creative and managerial activities of the first leader of a virtuous city, his wise rule, a category of happiness that he embodies in his management of the city, and so on and so forth. That is, we see that the above-mentioned semantic entities are outside of material existence, but at the same time they have actual intellect, without which, for example, it was impossible to achieve happiness by the inhabitants of a city, as a result of which the city is now called virtuous. In other words, actual intellect can participate not only in existence of material things, but also during the process of creating intangible substances, using which human intelligence can create its own socio-conceptual reality. Within the framework of social space, people from the very start begin to understand such abstractions as a state, good and evil, goodness, justice and injustice, etc. So, more global intelligence of man is needed for obtaining their correct meaning. In this regard, a certain form of actual intellect (in the form of human thinking) exists during the understanding of the above socio-conceptual substances. Here, al-Farabi writes that "the First is not in matter and has itself no matter in any way whatsoever, it is in its substance actual intellect" (Al-Farabi, 1998).

As discussed above, in the synthesis of four Aristotelian causes, the First One acts as an actual intellect, which brings the material nature, which has acquired the form of universe, to the First One itself, so that a natural cycle of existence of the four causes is again closed on the First One. "Humans and perhaps other higher beings indeed have both the power of thought and intellect. We expect humans to have such powers, but Aristotle words his statement 
about thought and intellect such that these may be additions to the other powers of soul in beings such as humans or even beings higher than humans, or perhaps such higher beings might have these faculties without needing to have them as powers of soul. Thus the issue how mind connects with soul is left open" (Polansky, 2007). However, this does not mean the end of the universe, but only the beginning of its transition to the next state of its existence. In its actuality the First One shows the priority of its existence over that which can exist only potentially. In Metaphysics, Aristotle writes: "We have distinguished the various senses of 'prior', and it is clear that actuality is prior to potentiality" (Al-Farabi, 1998). That is, if in the material world any potential matter may or may not exist (it all depends on the possible actualization of matter and on how much the form allows matter to be actualized in the form), then in relation to the First One it is always relevant.

On the example of a statue we can say that after a sculptor finished creating the statue (when all four Aristotelian causes merged) only one cycle of creating of one of the statues was completed. But at the same time, creative activity of the sculptor himself did not end there, but, on the contrary, reached a new next level of his perfection. The sculptor has become more perfect. His actual intellect which actualized existence of the statue has become more perfect. From now on, he became closer to the goal of his understanding of his own creativity; from now on the sculptor became even more aware of the world-wide purpose of his work. That is, after creation the statue, the sculptor became an even greater ontological beginning for his own existence as a sculptor and the existence for all future statues that he wishes to create. He even more deeply realized the producing cause (that is, himself and his creative ontology), matter (from now on he knows the methods of mastering matter and working with it), form (each time he creates new forms of statues) and the target cause (he realized his historical purpose to be or not to be a sculptor). All four of these Aristotelian causes together gave him an opportunity to come even closer to understanding the very creative process that could mean that the sculptor was aware of the process of divine being, or the being of the First One.

Therefore, it is no coincidence that those who not only possess a natural genius of creating masterpieces, but also constantly practice their creative genius of creating new works, say that they have a divine gift, or that they are gifted by God with some kind of talent. This applies not only to the job of sculptors, but also to the everyday produc- tion of material things, when an ordinary worker, applying his talent to combine the four Aristotelian causes together (truly realizing the essence of each of them, and not just creating things to feed himself), can even simple material things create as a masterpiece, or chef d'oeuvre. Thus magnitude cannot be applied to the First One, since it is outside of quantitative and material characteristics (which includes not only matter, but also all other essences and existents); and since it "is the First Mover who is incorporeal and source of all beings. Through the first intellect, the First Cause gives beings all incorporeal and corporeal existence in an emanationistic process. All beings are emanationistic extension of this necessary, perfect, and absolute beautiful Being" (Turker, 2011).

Thus, al-Farabi explains that the First One, as such, is neither intelligible matter nor the manifestation of any process of knowledge. However, in its hypostasis of actual intellect, the First One accepts matter (as an object) and cognition as a process of understanding the object (and, therefore, nature). In this sense, al-Farabi writes that the First One becomes both actual intellect and matter in its intelligibility, since matter acts as an object of intellect in the essence of the One. "In the same way that the sun is what gives the eye actual vision and makes [potentially] visible things actually visible by the light it gives, so too the active intellect is what makes the potential intellect an actual intellect by the principle it gives it, and by that same [principle] the intelligibles become actual intelligibles" (Al-Farabi, 2007). That is, the fact that matter is comprehended by cognitive ability of human intellect makes it an integral part of actual intellect, and hence the First One. Matter, as an object of intellect, and intellect itself are united in the process of comprehension of nature by the actual intellect itself, i.e., the One.

As the actual intellect, the First One possesses a property of self-knowledge, that is, as al-Farabi writes "it is intellect and intelligized and thinking, all this being one essence and one indivisible substance" (Al-Farabi, 1998). This process of al-Farabi describes as a process closed in its infinity. On the one hand, the essence of the First One cognizes its own substantiality; on the other hand, it symbolizes the most ultimate and universal process of self-knowledge. On the other hand, this process of self-knowledge is accompanied by infinity, that is, infinity as the most fundamental characteristic of universal self-knowledge does not enclose the isolation of self-knowledge of the First One. In this respect, self-knowledge is both a purely human process and a heavenly process, as many medieval 
Islamic philosophers believe. The same applies to intellect, to which al-Farabi emphasized in his ontology and epistemological treatises. That is, "intellection becomes self-intellection only when the intellect is fully developed and can therefore dispense with any reference to external material objects" (Kaukua, 2015). As well, the First One does not have any contraries which is a property of all material things. "The first being or cause can have no contrary since to have a contrary entail the possibility of nonexistence and whatever can possibly not exist cannot be eternal ('azali). For al-Farabi, contraries are forms of the possible and temporally generated" (Frank, 1979).

The process by which the First One intelligizes its essence is the process of manifestation the universal essence of the First One and its fundamental duration, which does not apply to the linear time of the universe, since, as noted above, the First One is outside of time as such. The First One is infinity, and everything that relates to it, characterizing it within the framework of a process, also deals with infinity. Of course, we have already touched upon the question above that nothing can characterize the First One, since it has no definition, and no entity different from the First One is capable to relate to the One in any way as an entity that can define it. However, the very thought of the First One already disposes the thought to infinity and, therefore, in its fundamental indefinability. Even in the most vivid human imagination, it is impossible to imagine infinity as the First One, since, firstly, infinity is the One (which it is impossible to imagine), and secondly, the First One in its essence is infinity. In this relation, infinity is identical to the First One, and therefore infinity is intuitively understood as something that is outside the semantic framework of the concept of time.

Here we implicate 'intuitive understanding', because, firstly, human logic in its entire methodological armory is hardly capable of endowing the human mind with ability to imagine the most fundamental and universal infinity, even in such a hypostasis as the One. Secondly, pure human imagination, aimed at embracing the immense infinity, is also based largely on sensory experience; in this regard, the imagination will somehow associate infinity with some sensory representation (for example, infinity is darkness, and therefore infinity is something totally black), which also limits infinity itself within the framework of specific representations of sensory experience. Thirdly, in the process of representing infinity as the One (at least, in space and time), even the most abstract state of meditating consciousness in any case will resort to associations that are associated with the rational, sensual, social and life experience of a meditating man. In this regard, the man cannot be freed from personal experience in order to achieve a state of pure consciousness, since the very realization that the man must achieve pure consciousness is based on the life experience that gave him knowledge that there is such a thing as infinity and in order to comprehend it, it is necessary to achieve a state of pure consciousness.

All of the above perhaps leads to the only hope - to an attempt to understand infinity (or, if you like, to touch the essence of infinity) through some deep intuition, that is, that subtle human ability that can shed light on the question of infinity. And even if intuitive understanding can give something to the human consciousness, there is no cognitive guarantee that the man will understand that he has encounter infinity.

For itself, the First One is comprehensible, since during the very process of self-knowledge the First One exposes itself as an object of ontic intellect which combines all levels of intellect from potential through the actual and acquired till the active one. Al-Farabi writes: "In order to be intelligible the First is in no need of another essence outside itself which would think it but it itself thinks its own essence. As a result of its thinking of its own essence, it becomes actually thinking, it is in no need of an essence which it would think and which it would acquire from the outside, but is intellect and thinking by thinking its own essence" (Al-Farabi, 1998). Of course, full knowledge of God is impossible due to His perfection, on the one hand, and imperfection of the human mind, on the other hand. Therefore, man has always tried, as it were, to understand what God is, not through His true attributes, but by excluding that which is not characteristic of God. This is so-called negative theology. "From ancient times to the present philosophers have commonly maintained that there exist one or more divine realities which are too perfect for human intelligence to apprehend and which therefore can only be the objects of a negative theology - that is a theology expressing not what a divine nature is but what it is not" (Wallis, 1992).

Although in the al-Farabi's typology actual intellect occupies the second level, this does not mean that the First One as an actual intellect is something secondary and therefore imperfect. The fact is that all levels of intellect (that express the First One itself as its existence and cognitive activity) are themselves perfect, because four levels of intellect are the levels of one intellect, which is an integral 
cognitive property of the One. The levels of intellect are the levels of universal mind which is identical to the essence of the First One. So, intellect "is intellect and intelligized and thinking, and so it is intellect by virtue of its being intelligized" (Al-Farabi, 1998). Therefore, gradation of intellect within the First One itself is for the most part conditional and convenient only for a greater understanding of world mind within the frames of human imagination of the essence of the First One.

However, as al-Farabi states, when the potentiality of the One Being affirms its own formation, there is a manifestation of universal activity of the First One as an expression of the actual level of universal mind, that is, more simply, it is a creative process of self-knowledge by the First One through actual intellect. In other words, through actual intellect, the First One actualizes its own infinite being, the volume and essence of which the human mind and imagination cannot capture. Here, al-Farabi incidentally points out that the One as an actual intellect "is intellect and intelligized and thinking, all this being one essence and one indivisible substance - whereas man, for instance, is intelligible, but what is intelligible in his case is not actually intelligized but potentially intelligible; he becomes subsequently actually intelligized after the intellect has thought him" (Al-Farabi, 1998). That is, al-Farabi explains that the First One is not intelligized by something outside, since this would mean the existence of something more extensive and universal, part of which the First One would be.

As already mentioned in the preceding paragraphs, something outside the First One and knowing the First One from the outside cannot exist, since otherwise it would be something that exists outside the First One and knowing it from the outside that would itself become the First One, which includes what is actually before this was not the First One. At the same time, this more extensive One would again be singular in its essence, and nothing more extensive than this One would not exist. That is, we again return to the question of the infinity of the First One and the inability to imagine something more perfect than the First One. Otherwise, if we constantly imagine something broader than the First One, we will encounter the Occam's unpleasant razor, which in the question of the One does not give any result, but only spends the time of a thinking person.

Thus, as al-Farabi states, the comprehending actual intellect and the object of actual intellect form a cognitive unity in the process of universal self-knowledge of the One, in which all aspects of self-knowledge are expressed in the process of self-reflection of the One as a singular Being of the universe. "The First is not only an intellect ('aql), but in addition the highest intelligible ( $\left.m a^{\prime} q \bar{u} l\right)$, which means that It is both thought and object of thought at the same time. It is, first and foremost, an object of thought for Itself, which means that It is constantly engaged in the act of contemplating Its own essence. In the case of the First, however, this self-reflexivity does not lead to multiplicity, as thought and object of thought is one and the same thing" (Hegel, 1991). This unity gives the First One a status of the very first substance, containing in its infinite existential duration of all levels of intellect that allow the First One to contemplate itself.

Here, al-Farabi clarifies the question of contemplation of actual intellect, aimed at the One's own essence, through understanding of human cognitive contemplation. In particular, he writes that in the process of comprehension a man is an intelligible object of a comprehensible actual intellect, or intelletion of the First One. However, a rational beginning in man (as not only an instrument of knowledge, but also a cognitive space for subsequent comprehension of the surrounding world) is only an object of intellect of One Being. Only when the rational beginning in man begins to become actualized in a process of human cognition, then we can talk about cognitive actualization of the human mind. But here al-Farabi makes an important point. Human intellect is purely human, i.e., human intellect is substantialized intellect. This means that human intellect is only one of the forms of actualization of the One's intellect, within which the man acts as a substantialized subject of knowledge. In other words, human intellect is the intellect of a specific substance, which can have its own conceptual boundaries. Al-Farabi writes that "we think, but not because our substance is intellect; we think with an intellect which is not what constitutes our substance" (Al-Farabi, 1998). Within the framework of human thinking, we can limit human rationality to any definitions and, thus, to outline the boundaries of human intellect (which cannot be done with the One's actual intellect, since, as noted above, the One has no definition due to the infinity of its essence). So, according to al-Farabi, everything that is within the framework of human intellect is determined by the objective nature of the objects that a man intelligizes. Therefore, human intellect is completely dependent on the content of the objects he intelligizes. In this sense, human intellect is too limited in comparison with the actual intellect of the First One, because "the 
First is different; the intellect, the thinker and the intelligible (and intelligized) have in its case one meaning and are one essence and one indivisible substance" (Al-Farabi, 1998). From here and further we will consider how al-Farabi shares his thoughts on what is the genesis of being.

As we have repeatedly found out, he considers the First One as the only cause of the surrounding universe. But here al-Farabi does not just discuss essence of the First One, but gives a definite ontological hierarchy, according to which being of the First One is the initial and most universal form of being, from which other ontological forms of realities flow in the world. Moreover, these existents arise from the First One in accordance with that essence which each of them needs to the extent of their possibility of coexistence with other existents and to the extent of their possibility to be observed by human intellect. As was noted more than once, being of the First One cannot be fully cognized by human intellect in view of imperfection of human mind, however, some other existents (known to us) lend themselves to perception and cognition, "some of which can be observed by sense-perception, whereas others become known by demonstration" (AlFarabi, 1998). We know that al-Farabi borrowed the idea of emanation of all existents from the First One from the Neoplatonists. Almost all his metaphysics is permeated with the idea of emanation, which allows us to see in his ontology an idea of a positive evolution of being and its hierarchy, which involves transition of one existence to another.

Further, explaining the First One as one which gives the material world to be emanated from it alFarabi follows Neoplatonic view on the First Cause. "Alfarabi is hugely influenced by Neoplatonic philosophy through his study of the theory of emanation and how this acts as a connection between the seemingly separate divine being and the material world." (Jackson, 2014). Here, he clarifies four aspects regarding to its perfection.

Firstly, process of emanation of everything in the world from the First One is an initially ontological process, which means a full-fledged emanation. At the same time, things and phenomena, which emanate from the First One in the world, in no way discredit the excellent essence of the First One and do not detract its perfection as the First Cause. That is, "the existence of something different from the First emanates from the First's existence" (AlFarabi, 1998) in contrast to what happens in human world when the birth of a son, as al-Farabi explains, takes away some existence of his parents. In this regard, the genesis of things and phenomena from the First One does not take away any excellence in it.

Secondly, al-Farabi emphasizes that process of emanation of existents in the world, moreover, enhances universality of the excellence of the First One. Here al-Farabi gives an example with the following: "when we give money $(m \bar{a} l)$ to others, we get from them honor or pleasure or some their goods with the result that these goods bring about some perfection in us." (Al-Farabi, 1998). In this case, the genesis of the universe from the First One gives its perfection one more proof of the First's fundamental nature.

Thirdly, al-Farabi says that in the process of genesis the First One is not attached to the world itself, that is, the creation process itself is not its goal in itself. If the First One existed for only genesis of the universe, then its existence would be determined by this creation process. In other words, the First One would be dependent on what it does. However, al-Farabi asserts, no external factor, including the process of creating everything in the world, is fundamental to its perfection. The First One "does not exist for the sake of anything else and not in order that anything else should be brought into existence by it" (Al-Farabi, 1998); otherwise, if the world that the First One had created was a cause of the First's perfection, then the First One could no longer be considered as the First Cause.

And fourthly, al-Farabi makes a correction that everything in the world which comes from the First One does not increase the First's perfection, but only more emphasizes its creative universality. In this case, the good that the First One brings to everything in the universe through the process of genesis is different from the good that a man does by giving money to anybody. In the case of the First One, "by giving existence to something else the First does not attain a perfection which it not have had before, apart from the perfection which it has" (Al-Farabi, 1998); whereas in the case of man, who having given his money or something else, then attains pleasure or honor or superiority or other benefits in surrounding social reality.

Thus, the highest perfection of the First One is its ontologically necessary hypostasis, which allows it to maintain a metaphysical priority over the world that emanates from it. Here the al-Farabi's First One can be compared with the idea of God. "Like Aristotle's Unmoved Mover, God is seen as one, eternal, immaterial and necessary. However, for Aristotle, his 'God' is the 'causer' in the sense of putting the universe into motion. That is, God is the First Cause of all other things but $\mathrm{He}$ is not 
the creator (efficient cause) of all other things. For Alfarabi, and for Islamic theology for that matter, it was unacceptable that there could be a separate substance from God: before God there was nothing and God created the universe ex nihilo ('out of nothing')" (Jackson, 2014).

Al-Farabi explains that being of the First One is all in one and integral, since it is expressed in its own perfection. It is thanks to infinite integrity that the First One transfers the perfection of its essence to other less perfect existents that emanate from it and form the rest material world. Being substantial cause for existence of the rest world, the First One maintains its fundamental excellence. The First One is that being which, as a substance, is present in being of everything else that emanates from its being. Al-Farabi also proves the integrity of the First One by the fact that it is all in one and cannot be divided into, for instance, two components, otherwise "one through which the substantification of its essence takes place, and another through which something else comes about from it" (AlFarabi, 1998). And further al-Farabi describes that the same could happen in human essence, when we consist of two things: one of them is the substantification that makes up our ability to think and the other, such as our ability to write, allows us to compose writings. Thus, the First's integrity in itself and identity with itself contribute to the fact that the whole world (with its various existents) has been allowed to emanate from the First One as the First Cause. Otherwise, according to al-Farabi, appearance of the world from two beginnings would not have been possible, since both beginnings would inevitably come into conflict with each other.

Al-Farabi describes self-sufficiency of the First One through absence of its emanation from anything that may turn out to be external to its universal essence. The First One itself emanates from itself; the First One is excellence emanating from itself without anything what can be external and therefore less perfect than it. For there is no more perfect the world than the First One in its fundamental nature in. Al-Farabi writes "Nor is it in need, in order for the existence of something else to emanate from its existence, of anything other than its very essence, neither of a quality which would be in it nor of a motion through which it would acquire a state which it did not have before, nor a tool apart of its essence" (Al-Farabi, 1998). The First One exists as the main cause for those causes that subsequently form various external conditions, which, in turn, affect the formation of other things and entities that have a lower degree of perfection than those secondary conditions.

If we trace a causal chain, within the framework of which any cause contributes to the formation of something else, then at the beginning of this chain there is something that we can call the Primary Cause. However, it is worth noting a very important point here: the closer we get to the Primary Cause, the more complicated and, at the same time, the more uncomplicated a previous cause in its ontological content becomes. Any previous cause is more complicated than the subsequent one because for appearance of something new (as a consequence), a whole complex of conditions corresponding to each other is necessary, which, if the external circumstances are successful, can lead to the appearance of something new that became a consequence of the previous causes. At the same time, any previous cause is more uncomplicated than its consequence, since something new (as a consequence) is a continuation of a whole complex of previous conditions. In this regard, approaching the Primary Cause itself, we understand that it is both complicated and uncomplicated. This understanding leads us to two consequences: the first is that the simultaneous simplicity and complexity of the First Cause is an invariant quality of its perfection (perfection of the First One is expressed in it); the second is that due to such fundamental perfection of the First One, we are unable to comprehend the simplicity and complexity of the First Cause at the same time, guided only by common sense and logic. As noted above, al-Farabi proposes to reach the level of actual intellect in order to use all human intellectual capabilities to be able to come into contact with the perfection of the First One and comprehend its universal essence somewhere in the very depths of human consciousness.

In this regard, al-Farabi explains imperfection of the material world by the fact that its objects need something external for their full manifestation of their own essence. For example, in order to see that fire can be as a cause of steam, water is needed, which fire can heat up and, thereby, extract steam from it. Or, in order for the Sun to take on the form that it has, the Sun itself needs to move. Also, thank to motion in space, the Sun is able to heat those parts of space that were far from it. That is, no matter how hot the Sun is, its heat is not enough for the whole space, so it needs to constantly move. In other words, the essence of the Sun is not so universal as to spread immediately to all space. Another example: in order to cut and chop a tree, a carpenter needs to have a wood chopper and a saw. We can 
give an infinite number of examples and in each we find imperfection of objects and phenomena in the material world, which is not the case for the perfection of the First One.

Al-Farabi emphasizes that in its perfection the First One has an inner identity of its existence and its substance. Its existence (as the essence of its reality) and its substance (as the ontological essence which the First One endows other existents emanating from it) are one and the same thing: both of these hypostases signify the identical perfection of one perfect essence of the First One. "God is omnipotent and there is no other fundamental principle to turn to" (Remes, 2014).

Regarding the process of emanation itself, other less perfect existents can flow from the First One without any obstacle. The First One manifests its perfection also in that it does not prevent the existence of something for no reason. "It is not at all possible that there should be something to prevent the emanation of the existence of something else from it, either in itself or apart from it" (Al-Farabi, 1998). This means that one of the most important goals of the First One is the existence of everything that has a possibility to exist and that can emanate from it.

In this regard, as we have already emphasized above, al-Farabi's thoughts are very close to Neoplatonism. "He is a neo-Platonist, more exactly a Plotinian; although he himself would not have recognized this title. He held, as we have seen, that he was simply retelling the doctrines of Plato and Aristotle. But he was also a devout Muslim" (Macdonald, 2008). At the same time, Plotinus himself introduces the concept of emanation "as a means of bridging the gap between the intelligible and the material worlds, on the one hand, and giving a coherent account of the coming-to-be of the universe from the One (to Hen) or First Principle, through a process of gradual overflowing or diffusion, on the other. This process generally known as emanation gives rise to the intellect (noūs), the soul (psyche) and the world of nature, in succession" (Fakhry, 2002). Anyway, uniqueness of al-Farabi's philosophy lies precisely in the fact that he was able to combine Neoplatonic ideas with his interpretation of Plato and Aristotle, moreover, without coming into conflict with Muslim views on the essence of the First One. This rich worldview synthesis allowed him to significantly expand his understanding of the First Cause and create such a deep metaphysical concept.

\section{Conclusion}

By virtue of all of the above, human intellect cannot act as an intelligible object for itself, that is, a man does not have any ability to complete self-reflection, while the actual intelligence of the First One in its own self-reflection reaches absolute identity with its own essence. "If the faculty of imagination is so powerful and perfected in a certain person, and is not completely overwhelmed by external sensations... it gets into communion with the agent [Active] intelligence from which images of the utmost beauty and perfection are reflected... Once the imaginative faculty in man is completely perfected, he may receive, when awake, from the agent [Active] intelligence the pre-vision of the present and future events... and thus... prophesy divine matters. This is the highest level to which imagination may be raised, and which man can attain through this faculty" (Sharif, 1963-1966). That is, human intelligence has the opportunity to come into contact with divine wisdom of the First One, but only by immersion in the essence of higher ontic intelligence, within the framework of which the First One reveals its potentiality of metaphysical knowledge to human intellect. In this sense, the immateriality of the First One acts as a kind of criterion for the truth of both the divine nature itself, as well as those substances that emanate from heavenly perfection and fall into the sphere of human intellect in order to become intelligible entities.

\section{References}

Al-Farabi Abu Nasr (1998). On the Perfect State (Madabi ara' ahl al-madinat al-fadilah). Revised Text with Introduction, Translation, and Commentary by Richard Walzer. Great Books of the Islamic World, Inc. Oxford University Press.

Al-Farabi Abu Nasr (2007). On the Intellect. Classical Arabic philosophy: an anthology of sources. Translated with introduction, notes, and glossary by Jon McGinnis and David C. Reisman. Hackett Publishing Company, Inc. Indianapolis. Cambridge. $416 \mathrm{p}$.

Buchli Victor (2015). An Archaeology of the Immaterial. Routledge. 190 p.

Fakhry Majid (2002). Al-Farabi, Founder of Islamic Neoplatonism. His Life, Works and Influence. One World, Oxford.

Frank Richard M (1979). Classical Islamic Theology and the Early Shi'a Movement. Islamic Philosophical Theology. Edited by Parviz Morewedge. State University of New York Press. 265 p. 
Hegel Georg Wilhelm Friedrich (1991). The Encyclopaedia Logic, with the Zusätze: Part I of the Encyclopaedia of Philosophical Sciences with the Zusätze. A new translation with Introduction and notes by T.F.Geraets, W.A.Suchting, and H.S.Harris. Hackett Publishing, Indianapolis. Cambridge. $381 \mathrm{p}$.

Hegel Georg Wilhelm Friedrich (2010). The Science of Logic. Edited and translated by George di Giovanni. Cambridge University Press. 790 p.

Heidegger Martin (1999). Ontology: The Hermeneutics of Facticity. Indiana University Press. 138 p.

Heidegger Martin (1962). Being and Time. Translated by John Macquarrie \& Edward Robinson. Blackwell Publishers Ltd.

Jackson Roy (2014). What is Islamic Philosophy? Routledge Taylor and Francis Group. London and New York. 190 p.

Janos Damien (2012). Method, Structure, and Development in al-Farabi's Cosmology. Leiden-Boston: Brill. 433 p.

Kaukua Jari (2015). Self-Awareness in Islamic Philosophy: Avicenna and Beyond. Cambridge: Cambridge University Press. $257 \mathrm{p}$.

Macdonald Duncan Black (2008). Development of Muslim Theology, Jurisprudence and Constitutional Theory. The Lawbook Exchange, Ltd. 386 p.

Morewedge Parviz (1992). Neoplatonism and Islamic Thought: Beyond Transnational Globalization. SUNY Press. 267 p.

Polansky Ronald (2007). Aristotle's De Anima. Cambridge University Press.

Remes Pauliina (2014). Neoplatonism. Routledge. 224 p.

Sharif M.M. (1963-1966). A History of Muslim Philosophy, 2 vols, Wiesbaden, Harrassowitz.

The Complete Works of Aristotle (1984). The Revised Oxford Translation. Edited by Jonathan Barnes. Vol. II. Princeton University Press.

Turker Habip (2011). Beauty and Its Projection in Christian and Islamic Tradition. Sharing Poetic Expressions: Beauty, Sublime, Mysticism in Islamic and Occidential Culture. Edited by Anna-Teresa Tymieniecka. Springer Science \& Business Media.

Wallis Richard T., Bregman Jay (1992). Neoplatonism and Gnosticism. SUNY Press. 531 p. 